\title{
Karol Samsel
}

Instytut Literatury Polskiej

Uniwersytet Warszawski

e-mail: lewks@wp.pl

ORCID: 0000-0002-2047-4508

\section{Norwid rubaszno-transcendentalny. Głos w sprawie intertekstualności "A Dorio ad Phrygium"}

Jeżeliby zgłębiać "A Dorio ad Phrygium" tak, ażeby narratora tego nieukończonego przez Cypriana Norwida poematu zrozumieć, a jego narrację zracjonalizować lub przynajmniej skonceptualizować - prędko doszłoby się do wniosku, że (zwłaszcza pod względem, o który tu chodzi, tzn. spójności intencji światopoglądowej narratora) poeta stworzył utwór kameleonowy, a nie tylko - jak zauważał Wiesław Rzońca - „kontrapunktowy"1. „Opalizowanie" wyżej wzmiankowaną intencją światopoglądową - bycia "doryjskim”, bycia "frygijskim”, bycia "pomiędzy” oboma, a nawet bycia "poza” nimi - jest tutaj elementem poliestetycznej (jeżeli nie transestetycznej) autorskiej gry, nie tylko samej retorycznej dialektyki. To zarazem cecha rubaszności $^{2}$ zarówno w jej nowożytnej, jak i nowoczesnej odsłonie.

1 W. Rzońca, Wieloperspektywiczność rzeczywistości. Gustaw Mahler i Norwid - „Pieśń skargi" a "Pierścień Wielkiej-Damy”, w: tegoż, Premodernizm Norwida - na tle symbolizmu literackiego drugiej połowy XIX wieku, Warszawa 2013, s. 307.

2 Na temat „rubasznego" pierwiastka "A Dorio ad Phrygium” mówi się i pisze w obrębie istniejącego stanu badań zaskakująco niewiele. W tekście Norwid - polski Hafiz? Renata Gadamska-Serafin sygnalizuje, że doszło w dziele do złączenia „epopeicznego z nieepopeicznym” oraz „subtelności z rubasznością". Autorka w tym, co „subtelne”, dostrzega oddziaływanie poetyki Hafiza. Tego, co „rubaszne” jednak nie dookreśla [R. Gadamska-Serafin, Norwid - polski Hafiz?, w: O Norwidzie komparatystycznie, red. M. Siwiec, Kraków 2019, s. 382]. 
Za podstawę myślenia o poemacie powinno się zawsze obierać bardzo wymowną, otwierającą go parabazę, ta odkrywa bowiem sensy i przesłania utworu, które potem będą $\mathrm{w}$ nim niuansowane, a nawet kwestionowane. $\mathrm{W}$ jej powoli postępującej analizie należałoby się kierować close reading oraz badaniem mikrofilologicznym. Nasamprzód - dochodzi do przemianowania postaci patrona poematu, "wezwanie" do Apolla "wymienia” tu bowiem narrator Norwida na "wołanie" do Apollina, zmieniając tym samym tryb uprawianej liryki z inwokatywnej na eksklamacyjną [III, s. 315]³. Już w wersach 1-5 sformułowany zostaje podstawowy, aporetyczny problem poematu: jest nim niemożność ustalenia światopoglądowej tożsamości narratora, mówiąc w wielkim skrócie - można go nazwać współczesnym Dorem czy współczesnym Frygiem? Odpowiedź na to pytanie jest utrudniona. Wymiana Apolla na Apollina stanowi tutaj sygnał ważnego wyboru światopoglądowego, ale nie idzie za nim upodrzędnienie jednego patrona kosztem drugiego. „Tyś rumieńcem dogmatu młodego ludu, / Tyś energii harmonią..." [III, s. 315], powie narrator "A Dorio ad Phrygium" o Apollu, od którego odstąpił... I chociaż Apollin przedstawiony został kilka wersów dalej w figurze flamandzkiego chłopa, "człowieka poczciwego" [III, s. 315], to jedynie Apollo jest $\mathrm{u}$ Norwida bogiem ludowych wiar - dokładnie tak, jak Antoniusz z Norwidowskiej tragedii Kleopatra i Cezar twierdzący, że "sam przenosi gminny rumieniec żyjących" [V, s. 143].

W Apollinie "harmonia energii" niegdysiejszego Apolla zmienia się w coś zupełnie innego - "harmonię barwy", związaną z dość nieudolnym (bodajże?) „braniem” tematów apollińskich i „klejeniem ich na mur" [III, s. 315]. Owszem, Apollin Norwida ma i "akademicki ton, i postać”, niemniej jednak wcale nie powinien $w$ ich ramach pozostawać wiecznie - niczym uwięziony. Jest tymczasem odwrotnie. Opis nieprzyjemnego status quo, którym Norwid otwiera parabazę "A Dorio ad Phrygium" bardzo w tym względzie przypomina wymierzone przeciwko „zafarbowanym słówkom krasomędrków" Źwierciadło, którym Mikołaj Rej inicjował Żywot człowieka poczciwego. Jak pisze Wojciech Ryczek, „występując przeciwko tak rozumianej sofistyce, [Rej - dop. K.S.] pragnął połączyć głoszenie prawdy z prostotą wysłowienia”, dlatego „w Żywocie człowieka poczciwego uwagi nad retoryką jako sztuką barwienia słów pojawiają się przy okazji rozważań nad eduka-

\footnotetext{
3 Wszystkie cytaty z utworów Norwida umieszczone zostały za wydaniem Pism wszystkich Cypriana Norwida w opracowaniu Juliusza Wiktora Gomulickiego: C. Norwid, Pisma wszystkie, zebrał, tekst ustalił, wstępem i uwagami krytycznymi opatrzył J. W. Gomulicki, Warszawa 1971-1976, t. 1-11. Miejsca cytowanych tekstów oznaczone są skrótem, w którym liczba rzymska oznacza tom, arabska - stronę.
} 
cją i cnotą prawdy" ${ }^{4}$. Przekonującym potwierdzeniem tego punktu widzenia jest w "A Dorio ad Phrygium" specyficzna definicja człowieka jako „Człeka", którą można by określić z powodzeniem mianem naturalistyczno-prymitywistycznej:

Człowiek jest to ktoś, co sobie idzie Gdzieś przez pole, i ty widzisz jego, Drogą jadąc. - Parskają twe konie "Człek" uchyla czapki i żegna się...

[III, s. 316]

Ad vocem rubaszności - warto zauważyć (za Januszem Tazbirem), że porównywanie Reja z François Rabelais'm zaczęło się jeszcze za życia Norwida. Na łamach „Biblioteki Warszawskiej” w 1877 roku wskazywano dość śmiało, że "«rubaszny Rej» pod wieloma względami przypomina swojego francuskiego kolegę [m.in. - dop. K.S.] «z krzepkiego języka wyjętego żywcem z ust ludu»" 5 (u Norwida - przypomnijmy - „rumieńcem dogmatu młodego ludu" był cenny skądinąd dla narratora Apollo). „Obaj pozostawali w kręgu wpływów reformacji, obu też - kontynuuje porównanie Tazbir zwykło się nazywać ojcami ich rodzimych literatur" ${ }^{\prime \prime}$. Słusznie przyjdzie tu na marginesie zauważyć, że (w kontekście literatury polskiej) Rej współdzieli ten tytuł z Kochanowskim - tym słuszniej, że dzięki owemu spostrzeżeniu można by odnotować istotną woltę estetyczną Norwida: "A Dorio ad Phrygium" dokumentuje bowiem chyba coś, co - w aspekcie stylizacji literackiej poety, a także jej głębokich, tradycjonalistycznych odniesień - moglibyśmy nazwać zwrotem "od Kochanowskiego do Reja". Jest on z pewnością źródłem cennych informacji tak o ewolucji twórczej, jak i estetycznej poety, ich rzetelna rekapitulacja wymagałaby jednakże oddzielnego (ewidentnie wyróżniającego "A Dorio ad Phrygium" jako tekst fasadowy) artykułu.

"Zacne blondyny silne w piersiach i w biodrach szerokie", Olimp, który "zielenieje warzywem”, Pegaz „biały i tłusty”, zdegradowana Muza jako „wypchnięta" samotnie przed szereg „praczka rękopismów” [III, s. 315-316] - wszystko to z powodzeniem dałoby się określić pantagruelowskim avant la lettre tonem poematu Norwida. Jak Tadeusz Boy-Żeleński stara się wyjaśnić, pantagruelizm „zrazu oznacza w ustach autora szeroką wesołość i grube

\footnotetext{
4 W. Ryczek, Zafarbowane słówka krasomędrków. Mikołaj Rej o sztuce barwienia słów, "Napis" 2015 , t. 21, s. 15.

5 J. Tazbir, Jeszcze o znajomości Rabelais'go w Polsce, „Pamiętnik Literacki” 1988, nr 2, s. 221.

6 Tamże.
} 
używanie, później stopniowo oczyszcza się, szlachetnieje i staje się synonimem pewnego pogodnego stoicyzmu" 7 . Ale to jeszcze nie wszystko, "Sterne, który w swoim Tristramie Shandy nieustannie czerpie z Rabelais'go, tworzy pojęcie shandeizmu, będące - jak uważałby Boy - jedynie wtórnym odbiciem pantagruelizmu" ${ }^{8}$. W obronie sternizującego aspektu stylu poetyckiego Norwida wiele cennych uwag wypowiedział Wacław Borowy, wpierw zasygnalizowawszy, że to, czy Norwid znał Sterne'a bezpośrednio, czy tylko przez uczniów i naśladowców, to sprawa mniejszego znaczenia. Natomiast, że „realizm jego i humor należą do typu sternowskiego - to jest niewątpliwie" ${ }^{\prime \prime}$. Łączy go to w przekonaniu Borowego zarówno (sensu stricto) z Józefem Ignacym Kraszewskim, jak i (lecz tylko toutes proportions gardées) z Marcelem Proustem, „potomkiem literackim Sterne'a” ${ }^{10}$.

Norwida lat 70. i 80. XIX wieku trudno nie czytać bez specyficznie formułowanej przez poetę autointertekstualności. Czasem - jest to wyłącznie autointertekstualna aura, czasem wszelako - autointertekstualność okazuje się tak wyrazista, że (niejako) „zdominowuje" intertekstualność całkowicie, stając się czymś w rodzaju "drugiego imienia” utworu. Stosunkowo niedawno pokazała to Kinga Borzęcka na przykładzie Miłości-czystej u kapieli morskich, wskazując, że z jednej strony jest ostatni dramat Norwida ironicznym rozliczeniem się poety z własnymi juweniliami, z drugiej jednak - stanowi sceptyczną autorewizję pomysłu o stworzeniu białej tragedii - wysokiej komedii z Pierścienia Wielkiej-Damy ${ }^{11}$. Tak rozumiana autointertekstualność wybrzmiewa również w parabazie "A Dorio ad Phrygium”. Nie jest tylko autoaluzyjnością. Apollin ma przybrać na siebie ciało Rejowego „człowieka

7 T. Boy-Żeleński, Od tłumacza, w: F. Rabelais, Gargantua i Pantagruel, przeł. i wstępem opatrzył T. Boy-Żeleński, t. 1, Warszawa 1949, s. 19.

8 Tamże, s. 33.

9 W. Borowy, Norwidiana 1925-1929, „Pamiętnik Literacki” 1930, nr 1/4, s. 178.

10 Tamże. Historyczne już dzisiaj paralele Norwid - Sterne, Norwid - Sterne - Proust przywołane tu zostały wyłącznie w celu unaocznienia skali wewnętrznego splątania recepcji. Szczególnie znamienny jest $\mathrm{w}$ tym wypadku wymiar skojarzeń - chyba nieprzypadkowo stosowanych do idiomatycznej poetyki Norwida, tak samo bowiem zestawiany był ze Sterne'em i Proustem Aleksander Fredro (poprzez eksperymentalną strukturę Trzy po trzy). Zob. m.in. W. Natanson, Epopeja napoleońska, w: tegoż, Sekrety fredrowskie, Warszawa 1984, s. 37-38.

11 K. Borzęcka, Impresjonizm poznawczy w "Miłości-czystej u kąieli morskich”, w: Dramaty Cypriana Norwida. Teksty - konteksty - interteksty, red. W. Rzońca, K. Samsel, Warszawa 2019, s. 231-232, 236. 
poczciwego", "nagie zawsze, nigdy rozebrane, / Ale ciało męża, co szaty zwlekł" [III, s. 315]. Opozycja nagości oraz rozebrania (tutaj dystynktywna, znacząca) organizuje całą spekulację liryczną narratora ballady Rozebrana z 1881 roku. To pierwszy autointertekst. Drugi mógłby z powodzeniem wskazywać na rejowo-rabelais'owski kult prostoty. "Ciało męża, co szaty zwlekł” zyskuje inną, pogłębioną wykładnię w kontekście dialogu Wiesław z Promethidiona: "duch ma dosyć ciężaru w szacie ciała!... Na cóż go jeszcze obciążać ciałem szaty?..." [III, s. 458], zwłaszcza że - ostrzega Norwidowski mąż ojcem szaty, ojcem zbytku jest szatan.

„Tak cię nieraz Holender obfitym pędzlem / Z dziewięcioma dziewki stawia na płótnie" (III 315) - mówi nieco dalej o Apollinie Norwidowski narrator "A Dorio ad Phrygium". Tajemniczego „Holendra" Elżbieta Feliksiak identyfikuje z Flamandem, Joachimem Anthoniszem Wtewaelem, autorem płótna Parnassus, rzekomo najbardziej zbliżonego do zakreślonej w poemacie sytuacji lirycznej ${ }^{12}$. Nie wikłając się jednak w dyskusje nad tym, o jakim konkretnie obrazie może być mowa, warto jest wskazać na inne, bo rubensowskie tło całej parabazy. Czy rzeczywiście o Petera Paula Rubensa mogłoby tu chodzić? "Muzy pchnięte z rękopismami”, "zacne blondyny”, „zieleniejące warzywa”, obrazy kreślone przez „mieszkańca mokrych równin”, ważny chyba sygnał "obfitości pędzla” - na autora Trzech Gracji powinny wskazywać.

„Pierwszym ich żywiołem wyobraźnia, drugim - święte zasady moralności", mówi Norwid w Krytykach i artystach o Rubensie, Jacopo Bassano oraz Buonarottim. To antynomiczna para, tu cyrkulacja "od żywiołu do żywiołu” rzeczywiście oznacza "a Dorio ad Phrygium”, czyli „od świętości do wyobraźni”, "od wyobraźni do świętości” i z powrotem, i po wielokroć. To zresztą cecha wspólna zarówno malarstwa Rubensa, jak i pisarstwa Rabelais'go. Parallel geniuses of the Renaissance, czyli „równoległymi geniuszami renesansu" nazwała obydwu wiele lat temu Katherine Kitt:

Tak, jak Rabelais jest jednym z ojców-założycieli nowoczesnej francuskiej prozy, tak też i Rubens - pozostaje ojcem-założycielem nowoczesnych technik malarstwa. Ten sam duch Renesansu, który rozkrzewił artystę-pisarza we Francji, rozwinął również artystę-malarza we Flandrii. Bujność, płodność i wylewność, które spełniły się poprzez słowa u Rabelais'go, zostały wyartykułowane poprzez krzywizny i kolory w pracach Rubensa. Energiczna myśl Francuza postaciuje się $\mathrm{w}$ cudownych umiejętnościach malarskiego warsztatu. Obaj byli przecież dziećmi Renesansu. Rabelais przejął chętnie pęd pierwszej fazy epoki do nabywania wiedzy, a następnie połączył z indywidualistycznym kwestiono-

12 E. Feliksiak, Dziedzictwo i pola wyboru. „A Dorio ad Phrygium”, w: tejże, Poezja i myśl. Studia o Norwidzie, Lublin 2001, s. 201. 
waniem wszystkiego i wszystkich oraz twórczą mocą z tych działań wywiązaną. Rubens przejął pojęcia rytmu i jedności zgromadzone przez Średniowiecze i wyrażone przez mistrzów włoskich, dalej zaś wplótł je w kręte linie natury i życia dookoła siebie. [...] Obydwaj mężczyźni dawali się unieść i zapalić własnemu postrzeganiu piękna, wykształcając w ten sposób umiejętność stwarzania arcydzieł, które miały przetrwać wieki ${ }^{13}$.

"A Dorio ad Phrygium" stanowi również przestrzeń dialogu z nowożytnymi koncepcjami optymizmu, tymi wyznawanymi przez Rubensa oraz Rabelais'go. „Optymizm” tego drugiego „głosi, że pogoda ducha i ewangeliczność pracy przekształcają się w pracę na rzecz ludzkości" ${ }^{14}$. Nie mniej Rubens - jak twierdzi Kitt - „głosi radość i pogodę ducha, a jego własne życie staje się przykładem niestrudzonego działania" ${ }^{15}$. Echa tych optymistycznych koncepcji wybrzmiewać mogą w poemacie Norwida: obserwujemy spacery po wsi bohaterów "swobodnie z-obcowanych”, słyszymy zapewnienia, że "-- Pogody równej / W oddechu płuc, w duchu, w biciu serca, / Czuć nie może, kto nie zna wsi polskiej”, wreszcie dowiadujemy się na temat serionickiego salonu, że „cowieczornym trybem arcypogodnym / zagaiła się całość serionickiego kółka / Całość błoga i zacna - -" [III, s. 328].

Nie chodzi tu tylko o spostponowanie estetyki idylli, czyli o jakiś deklaratywny gest wyboru jednej wizji świata kosztem drugiej - tak podobne ujęcia (niezwykle erudycyjnie) odczytywała Zofia Dambek, wskazując m.in., że Norwid krytykuje szlachecką idyllę w analogiczny sposób, w jaki Stanisław Brzozowski „trzy dziesiątki lat później obnaży płyciznę myślową Rodziny Połanieckich [Henryka] Sienkiewicza w przekonaniu, iż popularna kultura szlachecka, jej typy i ideały z Sienkiewiczowskiej powieści opanowały zbiorową wyobraźnię"16. "A Dorio ad Phrygium" nie jest jednak wyłącznie utworem rewizyjnym. Intertekstualność obserwowana w poemacie zwracająca nas w stronę Rabelais'go, Reja, Rubensa, idei swobody, pogody, rubaszności etc. - ma charakter filozoficzny, wskazuje na pojemność sensów, nierzadko w utworze kontradyktorycznych, i przekraczanie granic jednego rozumienia tekstu w obrębie jednej wykładni. Intertekstualność oznacza zatem w tym przypadku dla poematu Norwida jego radykalne zróżnicowanie: i wielowykładniowość, i (nie mniej) wielowykładalność.

${ }^{13}$ K. Kitt, Rabelais, the Man of Letters; Rubens, the Painter. Parallel Geniuses of the Renaissance, Arizona: The University of Arizona 1927, s. 41-42 [tłum. - K.S.].

14 Tamże, s. 41.

15 Tamże.

16 Z. Dambek, Wobec dworu - tradycja odrzucona. Wyspy umarlych ("A Dorio ad Phrygium" „Emil na Gozdawiu”), w: tejże, Cyprian Norwid a tradycje szlacheckie, Poznań 2012, s. 135. 
Dla przykładu - fragmenty o „pchnięciu Muzy”, „swobodnym z-obcowaniu", "arcypogodności trybów" przebywania ze sobą dawałyby się interpretować za pomocą Whitmanowskiego układu wartości, Waltem Whitmanem - mówiąc krótko. I chociaż transcendentalne, jest to odczytanie bliskie pantagruelowskiej aurze, w którą "A Dorio ad Phrygium" zostało spowite. Pantagruelowski wydaje się bowiem również sam wizerunek Whitmana: "gdy w 1855 roku po raz pierwszy ukazały się Źdźbła trawy, opatrzone były wizerunkiem autora w rozpiętej, mało eleganckiej koszuli, z ręką w kieszeni spodni - dalekim od nobliwych portretów, jakimi podówczas opatrywano tomiki szanujących się twórców"17. Whitman to zatem dość istotne ogniwo owego ważnego intertekstualnego wyliczenia - Rej, Rabelais, Rubens i... Whitman właśnie. Skupieni bowiem na czymś, co można by nazwać obserwacją intertekstualności "tonu doryjskiego" poematu, zapominamy o niuansowaniu strony "tonu frygijskiego". Intertekstualność tego „tonu" wydaje mi się w "A Dorio ad Phrygium" równie złożona, co intertekstualność "tonu" przeciwległego. Nie można jej sprowadzić wyłącznie do intertekstualności arystofanejskiej, jak (skądinąd niezwykle słusznie) wskazuje Zofia Dambek.

Jak przypomina Jakub Czernik, istotne dla zrozumienia autora Opiewam swoje Ja jest również „utożsamianie się z marginesem społeczeństwa”, „odczuwane nie tylko w stosunku do parobków i drwali, włóczęgów i robotników, sprzedawców i marynarzy, ale także do skazańców i ludzi pozbawionych praw"18. W "A Dorio ad Phrygium" reprezentantem wykluczonych oraz pozbawionych głosu jest Cygan, zderzający się w kolejnych częściach poematu z "martwicą" serionickiego salonu. Tak, jak w Dziadach cz. I Chór Młodzieńców pozostaje obojętny na przejmującą skargę Starca, tak też i u Norwida - jak pisze Zofia Dambek - „krąg ten obojętny jest na skargę Cygana, a właściwie nie dostrzega tej tragedii, rozmija się z nią, pojmując świat bardzo prosto i «zacnie»"19. Paralela z Mickiewiczem jest tu niezwykle istotna, bo Chór Młodzieńców postąpił wobec Starca w nader podobny, okrutnie „zacny" sposób, na co zwracała dokładnie uwagę Zofia Stefanowska w Próbie zdrowego rozumu:

Chór Młodzieży pełni funkcję uniwersalnego mędrca, uniwersalnego krytyka wszystkich od normy odbiegających postaci widowiska. Krótko mówi ten chór, dwa razy zaledwie głos zabiera, przecież udaje mu się obrazić uczu-

\footnotetext{
17 J. Czernik, Demokracja i równość w twórczości Cypriana Norwida i Walta Whitmana. Wstępne rozpoznania, w: O Norwidzie komparatystycznie, s. 236.

18 Tamże, s. 235.

19 Z. Dambek, Wobec dworu - tradycja odrzucona. Wyspy umarlych („A Dorio ad Phrygium" „Emil na Gozdawiu”), s. 141.
} 
cia wszystkich ze światem skłóconych bohaterów utworu. Widzieliśmy już, jak sobie poczynał z niewiastą w żałobie. Nie więcej taktu i zrozumienia jest w jego przemowie do Starca żyjącego przeszłością: „Tęsknota sercu i myślom szkodzi" ${ }^{20}$.

Wypadałoby w tym miejscu podsumować - Norwid buduje szkielet whitmanowskiej pod względem typu sytuacji, rozwiązuje ją jednakże Mickiewiczem, którego Dziady cz. I poeta może rzeczywiście mieć w dobrej pamięci, te bowiem, wydane pośmiertnie po raz pierwszy w 1860 roku, były mu prawdopodobnie znane. Na tropy mogące odsyłać do postaci Dziewicy trafiamy również podczas lektury Pierścienia Wielkiej-Damy - „rys Dziewicy” ujawnia się w przedstawieniach Mak-Yksa, co hipotezę o hybrydycznej intertekstualności Whitman - Mickiewicz wzmacnia. To już zresztą nie czysta intertekstualność, lecz krzyżowanie się intertekstualności z tzw. interfiguralnością (termin Wolfganga G. Müllera):

Jeżeli autor przejmuje figurę z pracy innego autora do pracy własnej - tłumaczy Müller - wchłania ją w obręb formalnej i ideowej struktury własnego utworu, wykorzystując na własny użytek, który może obejmować zakresy od parodii i satyry aż po fundamentalne przewartościowania, a ostatecznie i ponowne odkrycie rozpatrywanej figury ${ }^{21}$.

Rabelais'owski aspekt parabazy do poematu manifestuje się również w specyficznie pojętym ingerencjonizmie. Tym, co nasuwa tu na myśl Rabelais'go bezpośrednio, jest fakt, że w utrwalonym w "A Dorio ad Phrygium" ingerencjonistycznym obrazie literatury pierwiastek zdrowego, ludowego anarchizmu urasta (wręcz) do rangi narzędzia rewizyjnego, za którego pomocą dochodzi do kontrolowania doryjskiego przez frygijskie. Kontrolowanie owo jest dla historii literatury i kultury rzeczą zupełnie fundamentalną, programową (a i... programowaną) - realizuje ją u autora Assunty "lud klasyczny", zawsze szczerze reagujący na wyjałowienie czy spetryfikowanie form. Jak powiada narrator poematu, należy w momentach kluczowych „naglić formę wykrzykiem apostrofującym «Dlaczego nic nie ma gwoli Bachusowi?»".

\footnotetext{
20 Z. Stefanowska, Próba zdrowego rozumu, w: tejże, Próba zdrowego rozumu. Studia o Mickiewiczu, Warszawa 1976, s. 28.

21 W.G. Müller, Interfigurality. A Study on the Interdependence of Literary Figures, w: Intertextuality, ed. by H.F. Plett, Berlin, New York 1991, s. 107 [tłum. - K.S.].
} 
Ingerencjonizm istnieje dzięki kulturze rubasznej i przez nią zatem, ale tak, jak tłumaczy się w "A Dorio ad Phrygium" - rubaszność w specyficznym rozumieniu Norwida należałoby zawsze łączyć z rodzajem starożytnej anarchii pedagogicznej "ludu klasycznego". To w pierwszym rzędzie ruch anarchiczny, a więc ruch impulsu. Dopiero po czasie, wtórnie, mimowolnie okazuje się on działaniem pedagogicznym:

I lud dawny tak samo w teatrach,

Gdy długie go umartwiało patos,

Wołał przecież: „Dlaczego nic nie ma

W tych tragediach gwoli Bachusowi?"

Lud klasyczny więc wchadzał do Chóru,

Apostrofującym tym wykrzykiem

Naglił formę, tok przerywał z-rzędny,

Oratorstwem grożący na scenie.

„Śmiech to szczere królestwo człowieka", peroruje Rabelais w motcie do przedmowy do Gargantui i Pantagruela, przywołując jako patrona swojej księgi Bachusa i Sylena, Alcybiadesa - w funkcji tego pierwszego i Sokratesa - w funkcji tego drugiego. Sylen wszak miał być pierwszym „nauczycielem dobrego Bachusa”, a Alcybiades, „sławiąc swego nauczyciela Sokratesa, wśród innych słów, powiada o nim (jak podkreśla Rabelais), iż był podobny sylenom". Dalej Rabelais tłumaczy w "tonie" - mówiąc językiem Norwida i jego poematu - „niejednotężnym”, to jest "strony różne, rozliczny obyczaj - / Poznawając”, mając "słowo / Kolibrowym skrzące się skrzydełkiem”:

Syleny były to niegdy małe puzderka, takie jak widzimy dzisiaj w kramach aptekarzów, pomalowane $\mathrm{z}$ wierzchu $\mathrm{w}$ ucieszne a trefne figurki, jako to harpie, satyry, gąski, zające rogate, osiodłane kaczki, kozły latające, jelenie srokate i inne takie malowidła przedstawione uciesznie, aby ludzisków pobudzić do śmiechu, jako był zwykł Sylen, nauczyciel dobrego Bachusa ${ }^{22}$.

To samo centrum problematyki Gargantui i Pantagruela, wraz z kolejnymi inwokacjami do swobody, a także ze swoistym panteizmem marginesów świata eksponujących jego inność: „od cygańskiej drumli, co w zębach wre, / Jak zgryzione jestestwo konające, / I trzepoce się w wargach aż do organu" - przybliżamy się także do globalizmu Whitmana, którego wspólnotę z Norwidem najpełniej, chociaż dość jednostronnie, opisał Stanisław Brzozowski: „Gdy Whitman rozsyła pozdrowienia i błogosławieństwa Paryżowi, Europie, wszystkim stanom, całemu światu, wydaje się nam trochę

22 F. Rabelais, Przedmowa autora, w: tegoż, Gargantua i Pantagruel, s. 35. 
zbyt łatwą ta geograficzna ekstaza”, ,przychodzi nam na myśl ów heroiczny motyl Norwida, który był pewny, że ciągnie poza sobą rydwan świata" ${ }^{23}$. "A Dorio ad Phrygium" to (jednocześnie) potencjalny trop wiodący od Norwida do Rubensa i - odbiegłszy od Kochanowskiego (ten ruch ma u Norwida wymiar znaczący, być może wręcz emancypacyjny) - od Norwida do Reja. Wszystko to zaś układa się w istotną, intertekstualną sekwencję. Nie chodzi tutaj o to, których potencjalnych patronów „frygijskiej intertekstualności” Norwida ostatecznie w kontekście poematu dałoby się utrzymać. Jednych wymieniają lub mogą wymienić drudzy. Szłoby tu raczej o to, aby logikę owej intertekstualnej sekwencji (warto przypomnieć, ustanowiły ją ogniwa Rej - Rabelais - Rubens - Whitman) utrzymać w mocy, pamiętając zarazem, że należy pozostawać wrażliwym na rozproszone po całym tekście parabazy "A Dorio ad Phrygium" (i dalej, w głąb tekstu oraz jego fabuły) odniesienia autointertekstualne.

O wielu rzeczach nie sposób tu wspomnieć, dla przykładu o specyficznym, „epopeiczno-nieepopeicznym” pisaniu Norwida „na wszczęciu Odysei". To odległe i może nazbyt śmiałe skojarzenie, ale sposób, w który polski autor fabułę Odysei trawestuje na gruncie trywialnej, a także rozkiełznanej, serionickiej akcji, może nasuwać skojarzenia z tym, co z fabułą Odysei robi James Joyce, portretując Dublin w Ulissesie. Jak tłumaczy Mateusz Falkowski, to, co najbardziej dojmujące u Joyce'a, to „przytłaczająca rzeczywistość - znaków. To one mobilizując i emocjonując - pojawiają się w seriach i bez przywilejów, co prowadzi do dwuznaczności i zmienności. Świat bez horyzontu. Na czym polega jego epickość? Czym różni się od epickości starożytnej?" 24 - zapytywał retorycznie Falkowski. Jak zauważa Rzońca, u Norwida rzecz się ma niezwykle podobnie, co autor Premodernizmu Norwida - na tle symbolizmu literackiego drugiej połowy XIX wieku łączy ze stylistyką Mahlerowskiej muzyki:

23 Brzozowski nawiązuje do wiersza Whitmana Salut Au Monde! [M. Skwara, Whitman poetów i pisarzy polskich. Brzozowskiego "poeta życia”, w: tejże, "Polski Whitman”. O funkcjonowaniu poety obcego w kulturze narodowej, Kraków 2010, s. 219].

24 M. Falkowski, Pięć formuł filozoficznych, za których pomoca można scharakteryzować pisarstwo Joyce'a, „eleWator” 2012, nr 1, s. 19. "Zironizowaną wędrówką Odysową” nazywa z kolei „A Dorio ad Phrygium" Jan Mirosław Kasjan [J.M. Kasjan, Uwagi o "A Dorio ad Phrygium" Cypriana Norwida, "Zeszyty Naukowe UMK w Toruniu. Nauki Humanistyczno-Społeczne”, z. 2: Filologia polska, 1959, nr 1, s. 97]. 
Genialną realizacją nowoczesnego kontrapunktu jest Norwidowy poemat Co słychać?. Mojżesz, Faraon, Turcy i Litwini; fiołki, kapusta czerwona i zapałki (!) tworzą całość jako ruchomą, umysłowo-imaginatywną mozaikę, w której postaci pytan, godnych Mahlerowskiej XVII Symfonii zaistniewa cała ludzka kultura ${ }^{25}$.

Być może nie tylko więc w Ulissesie, lecz także - z zachowywaniem wszelkich proporcji, próbnie i prowizorycznie - również w "A Dorio ad Phrygium” „maniera literacka służąca odsłonięciu syntaksy rzeczywistości zmieniała się czasem w postulat egzystencjalny" 26: "Żydzi, Grecy, Irlandczycy, wszystkie imiona historii" 27 występują tu dość podobnie, jak u Norwida "Polacy i Cyganie”, tak samo „prawo, wyścigi, literatura... OMNIUM PO TRO$\mathrm{CHUM}^{28}$. Czy Joyce'owski postulat nie jest choć w części podobny do Norwidowskiego „ileż strun, ustrojów ile mam poruszyć? / Względów jak niemałą zachować liczbę" [III, s. 317]? Paralelne pod pewnymi względami wydają się także Serionice i Dublin jako (jak ujmuje sprawę Falkowski) "siedliska antybohaterów”, gdzie „antyheroiczna atmosfera ma być może głębsze uzasadnienie i nie sprowadza się jedynie do cech i ideałów jego mieszkańców” ${ }^{29}$, gdzie „wędrówka uczy czego innego" 30 , aniżeli uczyła w Odysei, na jej „wszczęciu" - jak powiadał Norwid:

\section{"A Dorio ad Phrygium"}

W Serionicach dziś jestem - Serionice / Że poważnym były ongi grodem, / Gwagnin pisze, kawaler Złotej Ostrogi, / I kronikarz inny to powtarza - / Kronikarze zaś cokolwiek skreślą, / Dla mieszkańców starczy - starczy ile? / Świadczą o tym baszty, gdzie stopa ludzka / Nie zbłądziła od lat niepamiętnych [III, s. 320].

\section{Ulisses}

Liczne i dostojne zebranie przyjaciół i znajomych z metropolii i okolic Wielkiego Dublina, których tysiące zgromadziły się, aby pożegnać Nagyasagosa orama Lipóti Yiraga, byłego współpracownika PP. Aleksandra Thoma, drukarza nadwornego Jego Królewskiej Mości [...]. Ceremonię, która odbyła się z wielkim éclat, cechowała jak najserdeczniejsza kordialność 31 .

\footnotetext{
25 W. Rzońca, Wieloperspektywiczność rzeczywistości. Gustaw Mahler i Norwid - „Pieśn skargi" a „Pierścień Wielkiej-Damy”, s. 307.

26 M. Falkowski, Pięć formut filozoficznych, za których pomoca można scharakteryzować pisarstwo Joyce'a, s. 18-19.

27 Tamże, s. 19.

28 Tamże.

29 Tamże, s. 18-19.

30 Tamże, s. 13.

31 J. Joyce, Ulisses, przeł. M. Słomczyński, Warszawa 1999, s. 457.
} 
Jeżeli mówienie o Jamesie Joysie w kontekście "A Dorio ad Phrygium" (dzisiaj zgoła abstrakcyjne i arbitralne) kiedyś okaże się możliwe, zasługę w tego rodzaju komparatystyce może położyć punkt wyjścia, który ustalony zostaje w tej chwili, a więc intertekstualność "tonu frygijskiego" poematu: Rej, Rabelais, Rubens, Whitman. Nie bez powodu Joyce przecież utrzymuje, że jego powieść jest, jak sam powiada, „bardziej epopeją ciała niż ducha ludzkiego" ${ }^{32}$. Mówiąc językiem Norwida (jeśli można w ten sposób), bardziej epopeją „frygijską" niż "doryjską". Krzysztof Cieślik daje szansę takiego niekonwencjonalnego czytania "A Dorio ad Phrygium”, które zbliżałoby rzeczywiście poemat do Joyce'a. Wskazuje mianowicie zbieżność wątków ideowych i filozoficznych utworu $\mathrm{z}$ teoriami relatywizmu kulturowego Ruth Benedict. Jak stwierdza wręcz, „wydaje się, że można czytać ten poemat zarazem w pewnym stopniu jako analizę kulturową w ujęciu Geertzowskim". Cieślik słusznie podkreśla: „nie trzeba mówić, jak wielkim w literaturze polskiej XIX wieku było to novum" 33 . Intertekstualność "A Dorio ad Phrygium" jest $\mathrm{w}$ tym ujęciu przyczynkiem do elitarności poematu; jak prowadzi dalej wywód Cieślik:

Sam zaś Norwid jawi się nam dzięki "A Dorio ad Phrygium” jako Bloomowski „silny poeta", który tworzy niezwykły, idosynkratyczny język i formułuje nowatorski opis rzeczywistości, broniąc się przed „potwornością, jaką jest odkrycie, że jest on tylko kopią albo repliką". W nieopublikowanym za życia poemacie przekracza barierę własnej epoki, wynajdując nowy literacki idiom ${ }^{34}$.

Zestawienie Norwida z Joyce'em poprzez sposób wykorzystania Odysei reprezentuje podobne oderwanie poematu od kontekstu literackiego, jakie wiele lat temu zaproponował Wiesław Rzońca, dostrzegając przede wszystkim w "A Dorio ad Phrygium" sposobność do dekonstrukcji dzieła poety. Choć autora niniejszego studium wiele od tej perspektywy dzieli, podąża on dosyć podobnym tropem, wykorzystując niespotykaną pojemność znaczeniową zawartą w Norwidowskim tekście. Owa pojemność sygnalizuje nie tylko kameleonowo wręcz ukrytą w "A Dorio ad Phrygium", potencjalną intertekstu-

32 Oświadczenie Joyce'a pada w rozmowie z Janem Parandowskim i warto przywołać je w pełnym kontekście, który naświetla stosunek pisarza do wzorca Odysei: „Such a thing cannot be done a second time; therefore, I took Homer's work and placed in its framework my nice little people, with their bodies and souls", "their bodies - poprawia się po chwili Joyce - Ulysses is more an epic of the body than of the human spirit" [J. Parandowski, Meeting with Joyce, "Studi irlanesi. A Journal of Irish Studies” 2015, no. 5, s. 139 - podkr. K.S.].

${ }^{33}$ K. Cieślik, Cyprian Norwid w kręgu relatywizmu kulturowego. Przełamanie ewolucjonizmu. Norwida wzór kultury w poemacie "A Dorio ad Phrygium", w: tegoż, Twórczość Cypriana Norwida a teorie ewolucjonizmu drugiej połowy XIX wieku, Warszawa 2017, s. 191.

${ }^{34}$ Tamże, s. 192. 
alność - quod erat demonstrandum - od Reja nawet do Joyce'a, lecz również prekursorstwo literackie avant la lettre, pozwalające zderzać ze sobą Serionice Norwida i Dublin Joyce'a jako dwie rozbite „znakowe rzeczywistości” - niezależnie od dystansu pół wieku dzielącego powstanie obu dzieł.

\section{Bibliografia}

Borowy Wacław (1930), Norwidiana 1925-1929, „Pamiętnik Literacki” nr 1/4, s. 170-185 .

Borzęcka Kinga (2019), Impresjonizm poznawczy w „Miłości-czystej u kąieli morskich”, w: Dramaty Cypriana Norwida. Teksty - konteksty - interteksty, red. W. Rzońca i K. Samsel, Warszawa: Wydawnictwo Wydziału Polonistyki, s. 225-237.

Boy-Żeleński Tadeusz (1949), Od tłumacza, w: F. Rabelais, Gargantua i Pantagruel, przełożył i wstępem opatrzył T. Boy-Żeleński, t. 1, Warszawa: Państwowy Instytut Wydawniczy, s. 1-14.

Cieślik Krzysztof (2017), Cyprian Norwid w kręgu relatywizmu kulturowego. Przełamanie ewolucjonizmu. Norwida wzór kultury w poemacie "A Dorio ad Phrygium”, w: K. Cieślik, Twórczość Cypriana Norwida a teorie ewolucjonizmu drugiej połowy XIX wieku, Warszawa: Dom Wydawniczy „Elipsa”, s. 184-190.

Czernik Jakub (2019), Demokracja i równość w twórczości Cypriana Norwida i Walta Whitmana. Wstepne rozpoznania, w: O Norwidzie komparatystycznie, red. M. Siwiec, Kraków: Wydawnictwo Uniwersytetu Jagiellońskiego, s. 227-240.

Dambek Zofia (2012), Wobec dworu - tradycja odrzucona. Wyspy umartych ("A Dorio ad Phrygium” - „Emil na Gozdawiu”), w: Z. Dambek, Cyprian Norwid a tradycje szlacheckie, Poznań: Wydawnictwo Naukowe UAM, s. 131-148.

Falkowski Mateusz (2012), Pięć formuł filozoficznych, za których pomoca można scharakteryzować pisarstwo Joyce'a, "eleWator" nr 1, s. 9-22.

Feliksiak Elżbieta (2001), Dziedzictwo i pola wyboru. "A Dorio ad Phrygium”, w: E. Feliksiak, Poezja i myśl. Studia o Norwidzie, Lublin: Towarzystwo Naukowe Katolickiego Uniwersytetu Lubelskiego, s. 171-212.

Gadamska-Serafin Renata (2019), Norwid - polski Hafiz?, w: O Norwidzie komparatystycznie, red. M. Siwiec, Kraków: Wydawnictwo Uniwersytetu Jagiellońskiego, s. 349-390.

Joyce James (1999), Ulisses, przeł. M. Słomczyński, Warszawa: Porozumienie Wydawców, stron 985.

Kasjan Jan Mirosław (1959), Uwagi o "A Dorio ad Phrygium" Cypriana Norwida, "Zeszyty Naukowe UMK Toruń. Nauki humanistyczno-społeczne", z. 2: Filologia polska, 1959, nr 1, s. 85-104.

Kitt Katherine (1927), Rabelais, the Man of Letters; Rubens, the Painter. Parallel Geniuses of the Renaissance, Arizona: The University of Arizona.

Müller Wolfgang G., Interfigurality. A Study on the Interdependence of Literary Figures, w: Intertextuality, ed. by H.F. Plett, Berlin, New York 1991, s. 101-121.

Natanson Wojciech (1984), Epopeja napoleońska, w: W. Natanson, Sekrety fredrowskie, Warszawa: Ludowa Spółdzielnia Wydawnicza, s. 33-46. 
Norwid Cyprian (1971-1976), Pisma wszystkie, zebrał, tekst ustalił, wstępem i uwagami krytycznymi opatrzył J. W. Gomulicki, Warszawa: Państwowy Instytut Wydawniczy, t. I-XI.

Parandowski Jan (2015), Meeting with Joyce, "Studi irlanesi. A Journal of Irish Studies” no. 5, s. 135-142.

Rabelais François (1949), Przedmowa autora, w: F. Rabelais, Gargantua i Pantagruel, przełożył i wstępem opatrzył T. Boy-Żeleński, t. 1, Warszawa: Państwowy Instytut Wydawniczy, s. 15-16.

Ryczek Wojciech (2015), Zafarbowane słówka krasomędrków. Mikołaj Rej o sztuce barwienia słów, "Napis", t. XXI, s. 13-32.

Rzońca Wiesław (2013), Wieloperspektywiczność rzeczywistości. Gustaw Mahler i Norwid"Pieśń skargi" a „Pierścień Wielkiej-Damy”, w: W. Rzońca, Premodernizm Norwidana tle symbolizmu literackiego drugiej połowy XIX wieku, Warszawa: Wydawnictwo Wydziału Polonistyki, s. 295-310.

Skwara Marta (2010), Whitman poetów i pisarzy polskich. Brzozowskiego "poeta życia", w: M. Skwara, "Polski Whitman”. O funkcjonowaniu poety obcego w kulturze narodowej, Kraków: Universitas 2010, s. 178-183.

Stefanowska Zofia (1976), Próba zdrowego rozumu, w: Z. Stefanowska, Próba zdrowego rozumu. Studia o Mickiewiczu, Warszawa: Państwowy Instytut Wydawniczy, s. $26-41$.

Tazbir Janusz (1988), Jeszcze o znajomości Rabelais'go w Polsce, „Pamiętnik Literacki” nr 2, s. 205-223.

\title{
Norwid, Coarse and Transcendental: The Case of Intertextuality in "A Dorio ad Phrygium"
}

\begin{abstract}
The article revises the existing critical discussion concerning the intertextuality of Cyprian Norwid's poem "A Dorio ad Phrygium". The author of the article demonstrates that the piece can be interpreted both from the perspective of the old-Polish intertextuality (his hypothesis concerns Norwid's inspirational address "from Kochanowski to Rej") as well as through "self-scrutinizing gestures" of the poet himself, who uses the intertext to refer to his own poetry. By reading the equivocal initial part of the poem, the author traces Norwid's intertextual affinity with Rabelais, Whitman or Rubens and points to the bawdy and transcendental nature of the work. These tropes explain the earlier radical readings of the poem by Wiesław Rzońca (deconstruction) or Krzysztof Cieślik (anthropology of Ruth Benedict or Clifford Geertz). While keeping these considerations in mind, the author of the article maintains, above all, the inter-textual perspective. The final part of the article juxtaposes the depiction of Serionice from "A Dorio ad Phrygium" with the Dublin of Ulysses and asserts that in both the topography is characteristically multidimensional (early modernist period) and relativistic (late modernist period) in its socio-cultural representation.
\end{abstract}

Keywords: intertextuality, bawdiness, transcendence, modernism, Cyprian Norwid 